\title{
Using Audio-Visual Aids and Computer-Assisted Language Instruction (CALI) to Overcome Learning Difficulties of Listening in Students of Special Needs
}

\author{
Sadeq Ali Saad Al- Yaari (Corresponding author) \\ Independent Researcher, Dept. of English, College of Arts, King Saud University (KSU) \\ Riyadh, Kingdom of Saudi Arabia \\ E-mail: prof.sadeq@gmail.com
}

Received: October 28, 2013 Accepted: November 10, 2013 Published: December 12, 2013

doi:10.5296/jsel.v1i2.4740 URL: http://dx.doi.org/10.5296/jsel.v1i2.4740

\begin{abstract}
Background \& aims: Audio-visual aids and computer-aided language instruction (CALI) have been documented to improve receptive skills, namely listening skill in normal students. The increased listening has been attributed to the understanding of other interlocutors' speech, but recent experiments have suggested that audio-visual aids and CALI should be tested against the listening of students of special needs to see the effects of the former in the latter. This investigation described the effect of audio-visual aids and CALI in the performance of these students.

Methods: Pre-and-posttests were administered to 40 students of special needs of both sexes at al-Malādh school for students of special needs aged between 8 and 18 years old. A comparison was held between this group of students and another similar group (control group). Whereas the former group underwent a listening course using audio-visual aids and CALI, the latter studied the same course with the same speech language therapist (SLT) with the classical method. Outcomes of the two tests for the two groups were qualitatively and quantitatively analyzed.

Results: Significant improvement in the performance was found in the first group (treatment group) $($ posttest $=72.45 \%$ vs. pre-test $=25.55 \%$ ) in comparison to the second (control) (posttest $=25.55 \%$ vs. pre-test $=23.72 \%$ ). In comparison to the males' scores, the scores of females are higher (1487 scores vs. 1411 scores). Suggested results support the necessity of the use of audio-visual aids and CALI in teaching listening at the schools of students of special needs.
\end{abstract}


Keywords: Listening, Receptive Skills, Audio-Visual Aids, CALI, Students, Special Needs, SLTs.

\section{Introduction Chapter}

\subsection{Introduction}

Audio-visual aids and CALI are associated with the improvement of language skills be it receptive skills or productive skills or even language components (Gilakjani, 2012). These educational aids are found to be useful not only for normal students, but also for students with special needs (Iram, 2012; Kirk, et al., 2012). Explaining the reasons behind the new trend, Kirk and his colleagues have rightly observed: "Such tests, in which acoustic variability is highly constrained, may not accurately reflect spoken word recognition abilities under more natural listening situations." (Kirk, et al., 2012: p. 455)

To study how audio-visual aids and CALI affect the ability of the normal students and those of special needs, improve their productive skills, some researchers went further to investigate the process of recognizing the word in the brain before it is articulated. According to them, articulation is the ice-berg of the pronunciation process which is preceded by brain process Bradham (2012). The operation takes place, according to Bradham when "Outer hair cells provide mechanical feedback into the organ of Corti, thus enhancing the input to the inner hair cells, which predominantly send information to the central nervous system." (Bradham, 2012: Abstract)

Such findings inspired researchers to ask legitimate and reasonable questions relating to the ways information are processed in the brain and the relationship between motion representation and the visual motion system (Pavan \& Baggio, 2013). More importantly, how and where does this process take place in the brains of students with special needs, especially when it comes to matters relating to deep/ surface reading for example (Wolf, et al., 2012) or those concerning Braille-reading and the way to understand issues like shape and space by blind students (Klingenberg, 2013). Onnis \& Thiessen (2013)'s findings suggest that mechanisms of statistical sequential learning are implicated in language across the lifespan, and experience with language may affect cognitive processes and later learning.

Others went further by investigating not only the patients, but also the role of the parents and other people around the child which results "in greater exposure to the majority language. (MacLeod, et al., 2013: p. 132) New trends of the research in this field started to focus on physicians and nurses and the way they read, write, etc. (Khaliq, et al., 2012; Peinhardt \& Hagler, 2013). Furthermore, scientists established a new trend whereby language aspects could be linked together. The study of Diaz-Maurin \& Giampietro (2013) investigated the impact of grammar for assessing the performance of power-supply systems. Having the nuclear energy and fossil energy compared to each other, the researchers concluded that when considering internal constraints, nuclear energy requires about twice as much power capacity and 5-8 times more labor. Diaz-Maurin and his colleague confirmed that things do not improve for nuclear energy when looking at external constraints which may explain the difficulties faced by nuclear energy to gain interest from investors. 
Despite of the fact that audio-visual aids and CALI made better progress in the levels of students, some researchers are still believe in the original methods as effective means through which students can acquire language skills, notably reading, listening and writing (Devimeenakshi \& Maheswari, 2012). Additionally, pedagogical-based aids were present with more theoretical views but not with more practical use. Consistent with the existing literature on other audio-visual aids and CALI, at least film is common in the field of education (Swimelar, 2013). Knowing the prevalence of boards, notably for teaching students of special needs supplements educational interpretation and can overcome the learning difficulties they suffer from? Many studies have been conducted in this field like Gessesse $\&$ Sileshi (2013)'s study whose purpose was to examine visual semiotic signs and bill-boards and their communication implications, especially if they are used for patients. It appears to in favor of this that Gessesse and her friend have forwarded the following notification: "all the visual semiotic signs on all these billboards would give a much wider picture of the types and applications of visual semiotic signs. For another, it would also provide greater opportunities to identify the genres of messages represented through these visuals semiotic signs" (Gessesse \& Sileshi, 2013: p. 246)

Students of special needs frequently encounter learning difficulties related to audio, visual or audio-visual texts. Some difficulties can be subtle but can seriously influence the students' ability to learn. The article of Brown et al., (2013) proposes that differing types of annotation offer a powerful and flexible technique for transferring the benefits of graph-based diagrams, as well as for reducing disorientation while moving around the graph and for tackling some of the inherent disadvantages of using sound. According to Brown and his friends, graph annotation may be performed automatically, creating a graph that evaluation shows requires less mental effort to explore and on which tasks can be achieved more effectively and more efficiently. Such results received high support from Chen \& Yen (2013) who concluded their study by providing insights on the design and instruction, not only for written text reading, but also for online reading.

The technological features of reading software that can be used for word recognition have not been explicitly investigated, but they may not be comparable because some techniques do not follow the same distinctive features and other qualities of others. The study of Damoiseaux, et al., (2012) may be a valuable source of information for refining our understanding of some of this software in general. Damoiseaux and his friends discussed the automatic reading of anti-neutrophil cytoplasmic autoantibody (ANCA-Slides). The purpose of the research team was to evaluate the AKLIDES System. The team emphasize that the results are promising in that the pattern recognition may play an important role in ANCA-associated vasculitis diagnostics. Some researchers investigated the idea of how blogs could be used for language purposes. The article of Álvarez (2012), for example, presents a study on the best ways of using blogs as a tool to improve students' reading and writing skills. The results showed that blogs are reliable tools for the improving students' productive skills. A total of 186 English as second language (ESL) elementary school subjects underwent the study of Ismail, et al, (2012). The aim of the study was to dis/prove whether or not using technology helps ESL learners improve their reading and writing skills. There are significant differences in the 
performances of the ESL students. This can be obviously seen in the outcomes of the qualitative and quantitative analyses of the scores. According to Ismaeil and his team, technology might play crucial role in assisting students to learn reading and writing skills. The researchers believe that “... computers have become powerful tools and important resources in the area of literacy (reading and writing). Technology is found to enhance better teaching and learning environments." (Ismail, et al, 2012: 266)

Other significant results, the researchers added, revealed that technology helped teachers in assigning extracurricular activities and communicating with students. Linguistically, there has been growing interest recently in the use of multimedia as audio-visual aids to decode information and facilitate messages from high-dimensional scientific facts and present them to English as foreign language (EFL) students. The study of Fuenzalida (2012) employed a support vector machine-based T.V approach to teach EFL students language skills, especially for young learners. Specifying what he aims to investigate, Fuenzalida has clearly noted: "I will argue towards the opportunity of generating public policies for digital television in order to create channels segmented for the children's audience. I will also highlight the cultural potential of the "educational" contribution that some children's television programs can make, particularly those targeted at children from birth to 10 years old, that is, the pre-school and elementary school stages." (Fuenzalida, 2012: p. 3)

Such results were highly supported by the study of Ahmed (2012). Gower \& McDowall (2012) assessed the role of interactive video games on educating children during the study of language skills and/ or language components. Eleven subjects ( 9 children and 2 music specialists) underwent the experiment. The two researchers concluded their study by recommending the use of audio-visual aids and computer-assisted/ aided language instruction (CALI) as useful educative means when they are used for teaching EFL students although "as with many cultural changes, this trend has not been universally applauded." (Gower \& McDowall, 2012: p. 91)

In their study, Anson \& Schwegler (2012) aimed at investigating tracking mind's eye technique. Anson and his colleague wanted to examine the usefulness of this strategy to be implemented for improving foreign language students' reading skill. Nevertheless, the study also highlighted the need for further research into how to improve such technique in composition studies, especially at the intersection of writing. Although currently only a few randomized controlled studies investigated the efficacy of tracking the movement of the eye, such outcomes received a great support by many researchers in the field who conducted similar studies (Henderson \& Luke, 2012; Perea, 2012).

Audio-visual aids and CALI had a strong internal and external consistency on the performance of the students. The test-retest and intra- and inter-rater reliabilities were shown to be adequate when it comes to talk about the effectiveness of the audio-visual aids and CALI, and the same thing applies to discriminant validity which was good in most of the conducted studies. For new techniques related to audio-visual aids and CALI, different outcomes were found: apart from one correlation, the scores on tests assessing a language skill and/ or a language component correlated significantly with outcome measures of similar 
methods. One of those methods is graphic organizer method designed by Manoli in 2012 . According to the researchers, the study constitutes an attempt to shed light on the research evidence regarding the effectiveness of graphic organizer on text learning and the various types of graphic organizers, which use different conventions to communicate information and are classified in various ways. The researchers finished their study by recommending ways of integrating them in reading lessons, touches on the issue of strategy instruction and its effects on language learning and leaves room for further exploration.

In the study of Marino, et al., (2013), eighteen adults with hearing problems were recruited in this study. The purpose of the study was to determine the efficacy of the round window application of the vibrant sound bridge in patients with mixed or conductive hearing loss. The study found that speech recognition in quiet results was not significantly different to performance attained whilst wearing hearing aids. Likewise, speech recognition in noise performance was substantially improved with use of the vibrant sound bridge in most test conditions. Vibrant sound bridge can be used as an effective method of hearing restoration for their mixed and conductive hearing loss.

Sigrist, et al., (2013) addressed the importance of technical display as means through which motor learning is enhanced, recommending using these audio-visual aids in addition to CALI. According to the research team, such audio-visual aids and CALI are important means that should be extensively used for teaching language skills due to their usefulness that can be clearly seen in the EFL students' multimodal feedback.

Previous studies suggest that listening comprehension as both ability and skill differ with both gender and ethnicity, making diagnosis of EFL students difficult. Thus, the study of Wright \& Uchanski (2012) investigated the importance of understanding the music. The researchers who implemented adults and non-adults in their experiment (10 and 25, respectively) concluded that listening to music is useful as a means of enjoyment through which one may enjoy educative listening in general. According to Wright and his colleague, music is rated as more enjoyable by cochlear implant users than by the normal hearing listeners hearing music through a simulation. Undoubtedly, what is meant by music here is all music items included in the questionnaire of the study. These, Wright and his colleague clarify: "included items on music listening habits, the quality of music heard through the patients' implants, and enjoyment of music.” (Wright \& Uchanski, 2012: p. 352)

Such results were greatly supported by another study (Pike, 2012). In addition, approaches' differences in using audio-visual aids and CALI associated with language skills' improvement including listening comprehension were also explored (Su \& Liu, 2012). According to Su and his colleague, "listening comprehension would be the hardest of all the four language skills." (Su \& Liu, 2012: p. 458)

Display modes of video captions on mobile devices, such as non- and/ or-full caption mobile devices, target-word modes, etc., are unique in that it requires one to make associations between words and non-literal meanings that are contextually appropriate. At the linguistic level, such devices have been linked to the improvement of the listening comprehension, namely for EFL beginners. Ching-Kun, et al., (2013)'s study examined these audio-visual aids 
and CALI to see their efficacy on the English listening comprehension and vocabulary acquisition of fifth graders. According to Ching-kun and his colleagues, the visual style students in both the English target-word group and the full-caption group viewed significantly better learning effectiveness in terms of vocabulary.

\subsection{Aims of the Study}

This study attempted to test the main and interaction effects of using audio-visual aids and CALI in the performance of students of special needs in listening skill. To this end, the researcher aims to find answers for the following questions:

1. What are the audio-visual aids and CALI that can be used for teaching students of special needs language in general and listening in particular? To what extent can SLTs benefit from them when teaching this class of students? What are the best methods that can be effectively used for implementing these educative aids in a way that guarantee improving students of special needs' performances.

2. Compared with those who do not use them, do audio-visual aids and CALI make any difference when they are used for teaching listening skill to students of special needs? Are there any results of other studies that agree or contradict the findings of the present study?

\subsection{Methodology}

Eighty students of special needs of both sexes (age ranges between 8-18 years old) were enrolled in this experimental study. The subjects were randomly divided into two groups; each group consists of 40 students. Nearly all students suffer different types of aphasias. They underwent a course on listening skill, for a semester (4 months) at al-Malādh school for teaching students of special needs in Dhamar city, republic of Yemen. The purpose of the study was to examine the effectiveness of audio-visual aids and CALI when they are used for teaching receptive skills in general and listening skill in particular. Before and immediately after the first listening lesson, the subjects under investigation performed a pre-test and at the end of the semester, another post-test was administered to them by their SLT who was teaching the two groups at the same school. In between the treatment, the first group studied using audio-visual aids, while the second group studied using ordinary methods (chalk and black boards). Outcomes of the two tests were linguistically and statistically assessed. In this regard, social program for social sciences (SPSS) was implemented to describe the frequencies.

\section{Analysis}

2.1 Using audio-visual aids and CALI to teach students of special needs language skills in general and listening skill in particular

Educative aids are frequently used in language practice to help students learn very well. Recently, psychoneurolinguists and speech language therapists (SLTs) have realized that using these aids is of special importance to students of speech needs. These divided the practical part of these educational aids into two broad categories: 
A. Conventional aids.

B. Computer learning in language teaching.

A very legitimate question that poses itself in this regard is the following:

Why do we use aids in language teaching in general and what are the benefits of using them for students of special needs? To answer such reasonable questions, one needs to understand that aids can be used for many language purposes. Some of these purposes can be listed as follows:

- Attracting attention (notably of those who are suffering from dysphrasia, blocking, etc.).

- Maintaining attention, especially if the students are suffering from alloesthesis.

- Clarifying concepts and meanings of words and utterances (e.g., those who are suffering from word blindness).

- Increasing chances of remembrance (especially for those who are suffering from prosopagnosia).

- $\quad$ Time saving (1 picture is worth 1000 words).

- Adding varieties to class activities. (For example, adding specific phonetic and phonological drill to teach those who are suffering from dysphasia, dyslalia, dysphonia, etc.).

- Compensation for the lack of experience in teachers (e.g., bringing pictures for throat to teach those who are suffering from paraphemia or aglossia to compensate for his inability to draw).

- Individualizing learning and teaching (e.g., giving students who are suffering from dysecoia or dysac (o) usia cassettes to be listened to at home or program instruction which takes forms like the book, for example, which is the simplest form and which contains some forms that have some bits of information and each bit of information has its feedback in the margins, etc.

- Involving learners: Either by asking them to participate in class activities or by using pattern practice which can be done by computer recording. Consider:

- John is reading a book.

- Mary....................

(Instant feedback varies according to the situation e.g., I'm sorry, good answer, well done, excellent, try again, etc. Such feedback is important, notably to those who are suffering from bradyesthesia).

- Presenting authentic language e.g., listening to a native speaker, giving menus to the students, recordings of airport's announcements, news, etc., especially for those who are suffering from lalophobia.

- $\quad$ Simulation of language use (e.g., acting, dramatization, etc.). 
Clearly, educational aids can be used for different purposes. We can use them for teaching language skills and language components. In detail, educational aids can be used for teaching oral skills (listening and speaking) and written skills (reading and writing) and components of language (sound system, grammatical structures and vocabulary building) to those students who are suffering from various language deficits like aglossia, alalia, acoustic agraphia, dysarthria, etc. Educational aids for teaching language skills and language components fall into five major types: Visual aids, audio aids, audio-visual aids, action (e.g., dramatization, field trips, debating, etc.), and multi-media (Computer-assisted language learning/ instruction/ teaching (CALL/I/T)).

1. Visual aids: These aids are very important to those who are suffering from paraphasia, dyspraxia, cerebral agraphia and other language impairments. This type takes different forms and shapes:

a. Realia (Real things). This includes chalk, board, chair, etc.

b. Three dimensions models (e.g., trains).

c. Pictures or drawings: These can be photographic or hand drawn. There are different types of pictures:

$\checkmark$ Simple pictures: Pictures of cars, pens, books, etc.

$\checkmark$ Composite pictures: Pictures of scenes in classes, movies, etc.

$\checkmark$ Series or sets: For example, telling stories, process of doing something (cooking, manufacturing, experiment, etc.), pictures of transportation means, etc.

d. Posters: Usually consists of picture and text (e.g., posters of "No Smoking").

e. Maps: These include geographical maps (used for topographical purposes), political maps, city plans, floor plans, etc. SLT can use city plan for example and ask the student who suffers from dyslexia to follow his instructions by drawing lines on the places he/ she is talking about.

f. Boards: There are many of them like smart boards, white boards, black boards, etc.

g. Cards: These include flash cards (where the picture is in one side and the word is in the other side), reading cards, and question $\&$ answer cards, etc.

h. Graphs: One of the most famous graphs is the pie graphs. Pie graphs are normally used for statistical purposes.

i. Forms: To be used by students who are suffering from dysgraphia for example. Examples of forms: Immigration forms, customs forms, hotel forms, etc.

j. Menus: Restaurant menus that can be used to teach mentally handicapped students something about cultures, traditions, folklores, etc.

k. Slides: Overhead projectors (OHP) slides and $35 \mathrm{~mm}$ slides are some of the example for this type of visual aids. Many of the above mentioned visual aids can be converted into slide forms and then presented to the students of special needs to achieve some class activities.

1. Film strips: It is a set of slides like picture series. SLTs can also make use of silent films.

m. Comic books: Examples of this type are children books, stories, etc. that can be used to entertain children, notably those who have problems relating to dyscalculia. Such type also attracts the attention of students suffering from dysarthria and prompts them to speak.

n. Facial diagrams: Diagrams to be taken from books like phonological books or even by drawing them on the boards for teaching purposes like teaching articulation for those who are suffering from pronunciation problems. 
o. Clock, face, and hands: By asking the students to assign the time according to the question or vice versa. Such types of activities help dyscalculic students learn better.

p. Calendars: For counting days of the week, months of the year, numbers, etc. Again, such drill helps those who suffer from dyscalculia.

q. Letters of the alphabet and numbers: For teaching spelling, recognition of the letter, etc.

r. Cross-word puzzle: For teaching vocabularies. We also have scrabbles. Learning vocabulary items is very helpful for those who have developmental aphasia.

s. Tables \& schedules: These include time table, flight schedules, tec. Linking information to each other helps those who have global aphasia as it strengthens their abilities to speak and comprehend.

2. Audio-aids: Some audio aids that can be used for students who have language difficulties notably those who are suffering from anepia, bradylogia, bradyphasia (bradyphrasia), bradyphemia and other language impairments are:

- Cassette recorder or radio: Such audio aid is typical, notably for those who have problems related to Wernicke's aphasia as it helps them comprehend what they are listening to. Those who suffer from conduction aphasia may benefit from these cassettes also as they have to repeat the words and / or phrases they are listening to. In others, they do not have to listen to themselves and repeat their own sentences more than one time.

- Phonograph records: It is an old version of compact disc (CDs).

- CDs.

- Conversional language labs: In this kind of labs, one can have all the above mentioned audio aids.

3. Audio-visual aids: Such educative aids are of special importance, notably for those who are suffering from cataphasia or those who have mental problems related to unconscious cerebration. The most obvious types are T.V, videos, and also digital versatile disc (DVD) which has almost the same function as the video tape. Sophisticated language lab is another audio-visual aid. In this kind of labs, students of special needs can have both recording and playing. They can also have the facility to speak and listen at the same time and then compare that. Another characteristic of these labs is the facility of instant repetition. Sound movies are also some other types of audio-visual aids. These movies are now replaced by video tapes. Sound movies are the opposite of silent movies. SLTs can mute the sounds so that movies can be functioned for speaking or with the sound for listening. Slide/ sound synchronization is another type of audio-visual aids. In this type, students of special needs can have both sound and picture and this is used to be one of the methods used in the past and is called in French "La method audio-visuelle".

4. Action: It is very useful in language teaching, notably for teaching students who are suffering from aphonia (paralytica \& hysteric), apsychia and other language impairments. This type takes different shapes and forms:

- Dramatization (physical action) like walking, standing up, etc. Such exercises are helpful for students suffering from Alalia. However, if the SLTs notices that his/ her student cannot act 
the action, then they can ask them (using sign language when necessary) to pantomime or imitate.

- Charade: Charade is a good exercise due to those students of special needs enjoy it so much. In this type of exercises, SLTs are supposed to play a role of something and their students predict what it is.

- Party games: Many of them can be used be used as means for teaching language skills in general.

- $\quad$ Language teaching games: They can be found in magazines, etc.

- Field trips: They teach students of special needs some vocabularies. Students of special needs can also get practical experiences with them.

- Role playing: It is a good example of actions.

- Physical response: It is considered one of the ways of performing actions.

5. Multi-media aids (CALL/ CALT): These educational aids can be effectively used to teach students who are suffering from different aphasias' types including apsychosis, audimutitas, etc. Multi-media aids are combination of all the above mentioned aids including the use of internet, etc. Nor must we forget some general programs like T.V, radio, etc. SLTs should also pay attention to the use of computer as only one aspect of aids in language learning.

It is important, however, that SLTs know the best ways to use the above mentioned educative aids in teaching language to their students of special needs. Some requirements for proper use of these educational aids (selection $\&$ use) are as follows:

* Aim (objective): In this regard, SLT should ask himself/ herself "Why am I using this aid in particular (a picture for instance)? Why not another/ other aid(s)?"

* Effectiveness: Again, SLTs should ask themselves questions regarding to the effects (positive, negative, or side effects). Examples of these questions are: How effective is the use of this educative aid? What shall I do to make that educational aid more effective bearing in mind time, environment, students' levels, individual differences, types of language disorders, etc. For example, a documentary art subject will help students with dysmnesia remember things: Should I use it as a whole or just segment it in sections? When shall I use it? Shall I use it at the beginning, in the middle or at the end of the class?

* Resources: Questions relating to the availability of the educational aids. These include: Where can I get the educative aid (s)? Are they available in toys' stores, bookstores, or internet?

* Preparation: Making sure whether this educational aid is useable or not (usability of the educative aids and the best way (s) to use it.

Let's take an example of using these educational aids for teaching listening comprehension. For understanding oral messages, there are some requirements for that and these can be listed as follows: 
冈 Recognizing sound systems and discriminate them.

囚 Grammatical structures and functions (Vsual aids).

冈 Vocabularies (Meanings of lexical items).

囚 Discourse markers (Connecting sentences together), translation, expressions e.g., however, therefore, although, otherwise, thereafter, because, thus, hence, etc.

冈 Discourse signals (Para-linguistic signals) including facial expressions, gestures, body actions, etc.

Ðunctions: In this regard, an important note that should be considered here is the same structure can be used for different functions but not every function can be used for the same structure. Consider:

$\otimes \quad$ Can I use the phone?

Is there a phone?

囚 I need to call my family?

A very legitimate question now is: What do the SLTs need these requirements for? To answer this question, SLTs need to understand the major types of texts. In other words, they need to understand the nature of text. Is it authentic (natural)? like an announcement from a public place (e.g., an airport announcements, etc.). Another type of text is the simulation where the SLTs take the authentic text and imitate it like writing the announcement of the airport and/ or recording it and then discussing it with their students of special needs. Text also can be live (e.g., when the SLT asks his students to record something directly) or recorded which, in turn, can be authentic (when it is recorded). However, they should pay attention here that if the SLT writes the text and imitate it, then it will not be authentic anymore; rather, it will be simulated text (imitation for the real). Similarly, the mode of presentation could be live (e.g., a guest presentation, video conference, etc.), audio-recording, audio-visual recording or reading by the SLT to test his students' listening comprehensions and this type of modes is the worst.

Technological aids to be used for teaching students of special need listening comprehension can be, psychoneurolinguistically speaking, divided into three main types:

1. Conventional labs: The significance of these labs is that they can be effectively exploited to teach those who are suffering from different language problems like alogia, color anopsia, anacousia, etc. Basically, they are of different categories. For example, listening labs is the first kind where each students of special needs has a headphone and that is the feature that distinguishes this kind of labs from class tape recorder as here, the students of special needs hear clearer. Additionally, they are connected to other classmates (distributers). Sometimes, they have wireless headphones. In this lab also, the students of special needs can benefit from all kind of electronic audio-visual aids on the monitors of their computers. This kind of labs is also called audio-passive labs. From a functional point of view, students of special needs have headphones and they listen to their voices. These laboratories also consist of master recorders 
controlled by the SLT. They are also called passive because they do not have microphones. In other words, the student of special needs can listen, but he/ she cannot hear himself/ herself clearly due to bone conduction.

1. Active listening labs: Compared with conventional lab, this lab is more developed where headphones, microphones, etc. are available. Put in other way, there is microphone attached to the headphone; that is why, it is also called audio-active labs. SLTs can make use of these labs to teach students who are suffering from letter blindness, bradyarthria, and bradyecoia.

2. Listening, recording and comparing labs: These labs are, psychoneurolinguistically, good for those who are suffering from bradyglossia and bradylalia. In tis lab, each students of special needs has his/ her own tape recorder which is, of course, different from conventional tape recorder, because in this one, there are two head work separately. This means that students of special needs can record and play or play and at the same time compare it with what has been already played in terms of comparing them. Strictly, in a good lab, there must be a console, control panel (to control all or individual booths or groups of them. SLTs may communicate with individuals or with groups), sound sources (real or cassette, tape recorder, CD, video recorder, radio, etc.), and recording facilities. Booths consist of tape recorder with listen (play), record and at the same time compare (listen to master recording and compare what he/ she (the student of special needs) has said), instant repeat, speed control, but buttons for communication with SLTs.

Now, the question is: How can SLTs prepare a material to record it in this type of labs? To answer such question, they need to pose another question: Why am I recording? Am I recording to teach dictation? Dialogue?, etc. Once they have decided to record, they have to prepare the material. The instructions should be clear. The rate of the delivery should be natural. They should also have silence blanks for students' response. They can control it by repeating the utterance twice before they provide the appropriate feedback/ re-enforcement by giving short time to allow students of special needs to answer. They can also pause the recording for seconds, or they can break the sentence, but this break has to be prepared for the utterance which means that it has to be at the end to allow students of special needs understand the intonation pattern. Finally, if SLT segments any sentence or utterance, he/ she should not move to the second sentence before he/ she says it in a whole. SLTs also should provide details at the beginning that are related to the subject they are going to address/ talk about. It is also a good thing to leave an adequate blank at the beginning and also at the end. Last but not least, SLTs should clearly understand that the text he/ she is recording should be made as a full transcript with proper and clear directions.

Clearly, labs can be used for teaching listening comprehension to students of special needs, especially if these students are suffering from laloplegia, laryngopathy, or logoneurosis. Moreover, they are also good educative means for teaching loud reading dictation, dictation, grammatical exercises (pattern drills), writing and speaking skills to some extent (e.g., dialogues, conversations, etc.), language components (mainly sound system and grammatical functions), assessment (testing listening comprehension), pronunciations, controlled communication, etc.). Such labs can have several characteristics including individualization 
facility and unlimited practice, immediate feedback, good for shy students of special needs, etc. Notice here that labs are hardware and what makes them useful is the software.

In order to prepare a lesson on listening comprehension for the lab, SLT has to do the following:

Set the objectives.

* Prepare a transcript.

\# Prepare the instructions for recording.

Make his/ her breaks comprehensible.

\# S/he should not record on cassette, but on reel (faster, easier and more fidelity).

\# Good labs have cassette copies.

Furthermore, radio, T.V, video, etc., can be differently used as teaching means (full course) as can be seen in the B.B.C show "Calling all beginners". SLTs may often have supplementary materials (e.g., booklet, recordings, tests, etc.). Any other second use of the above mentioned educative aids can be viewed as either complementary to class work or source of audio-visual aids and materials or at least a source of general practice. Rdio programs can be psychoneurolinguistically implemented to teach those who are suffering from hypomnesis, logagnosia and other language problems.

T.V can be used as a supplementary educative aid by asking students of special needs to listen and/ or watch a program. It can also be used as a course/ partial course (supplemented by the SLTs course). An important advantage of using the T.V is that it combines efforts from different sources. Authentic language speaker can also be used in addition to CDs programs like Fellow me (British English), or Fellow me to San Francisco (American English). SLTs can also make use of Open University learning where the system allows using occasional live classes to be conducted as a source of audio-visual materials. Radio can also be used the same way as T.V. The difference between the two remains in that while in radio, SLTs can only make use of intermediate language, in T.V, nearly all audio-visual aids are involved which gives the students of special needs more than one option. Additionally, we can use them to teach those who are suffering from lalopathy, typhlolexia, thymergasia, etc. In clearer terms, on T.V all information, cartons, animation, graphs, photographs, etc., are provided. Some advantages of the above audio-visual aids and CALI, notably labs, radio and T.V can be summarized in three major points:

1. Group resources (Educational aids, experts, etc., to work together in a team work).

2. Compensation for the lack of experience of the teachers.

3. Presentation of real situations.

\subsection{Audio-visual aids and CALI: Effects in the performance of students of special needs}

The same version of the listening pre-test was used to reliably estimate subjects' performance 
in both experimental and control groups, and the results can be compared to each other to dis/prove such assumption. Such unified test allow for the measurement of change (if any) in an individual's listening ability. Table 1 below summarizes these results of the pre-test for both experimental and control groups. Consider:

Table 1. Performance of the subjects in the pre-test: Comparison between the treatment and control groups

\begin{tabular}{|c|c|c|c|c|c|c|c|c|}
\hline \multirow[b]{2}{*}{ No } & \multicolumn{4}{|c|}{ Treatment/ Experimental group } & \multicolumn{4}{|c|}{ Control group } \\
\hline & Subject Name & 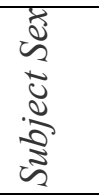 & 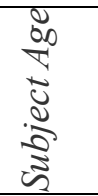 & 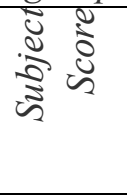 & $\begin{array}{r}\text { Subject } \\
\text { Name }\end{array}$ & 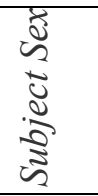 & 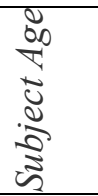 & 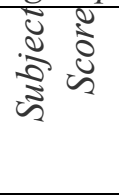 \\
\hline 1 & Saleh & $\mathrm{M}$ & 18 & 33 & Nada & $\mathrm{F}$ & 15 & 38 \\
\hline 2 & Majed & $\mathrm{M}$ & 12 & 12 & Hajar & $\mathrm{F}$ & 14 & 28 \\
\hline 3 & Saqr & $\mathrm{M}$ & 14 & 34 & Hamas & $\mathrm{F}$ & 8 & 12 \\
\hline 4 & Ali & $\mathrm{M}$ & 8 & 12 & Rashad & $\mathrm{M}$ & 12 & 9 \\
\hline 5 & Amatallateef & $\mathrm{F}$ & 12 & 11 & Omar & M & 9 & 11 \\
\hline 6 & Amatala'leem & $\mathrm{F}$ & 9 & 18 & Ashraf & $\mathrm{M}$ & 16 & 14 \\
\hline 7 & Badr & M & 13 & 23 & Mohammad & $\mathrm{M}$ & 11 & 26 \\
\hline 8 & Tareq & $\mathrm{M}$ & 14 & 28 & Montaha & $\mathrm{F}$ & 14 & 23 \\
\hline 9 & Parees & $\mathrm{F}$ & 15 & 29 & Ayman & $\mathrm{M}$ & 13 & 28 \\
\hline 10 & Bayrout & $\mathrm{F}$ & 9 & 8 & Aayah & $\mathrm{F}$ & 10 & 18 \\
\hline 11 & Tammaah & $\mathrm{M}$ & 9 & 16 & Adham & $\mathrm{M}$ & 10 & 17 \\
\hline 12 & Taher & $\mathrm{M}$ & 17 & 19 & Nasser & $\mathrm{M}$ & 11 & 17 \\
\hline 13 & Baraah & $\mathrm{F}$ & 16 & 20 & Haylah & $\mathrm{F}$ & 17 & 15 \\
\hline 14 & Abrar & $\mathrm{F}$ & 11 & 39 & Tawfeeq & $\mathrm{M}$ & 13 & 12 \\
\hline 15 & Ahmad & $\mathrm{M}$ & 13 & 42 & Nour & $\mathrm{F}$ & 12 & 33 \\
\hline 16 & Fatimah & $\mathrm{F}$ & 16 & 16 & Najeebah & $\mathrm{F}$ & 18 & 28 \\
\hline 17 & Amatillah & $\mathrm{F}$ & 18 & 23 & Radha'a & $\mathrm{F}$ & 16 & 40 \\
\hline 18 & Abdullateef & $\mathrm{M}$ & 8 & 20 & Wafa'a & $\mathrm{F}$ & 15 & 29 \\
\hline 19 & Amriyah & $\mathrm{F}$ & 12 & 40 & Wajedah & $\mathrm{F}$ & 15 & 28 \\
\hline 20 & Abduljaleel & $\mathrm{M}$ & 12 & 37 & Sultan & $\mathrm{M}$ & 9 & 24 \\
\hline 21 & Kareemah & $\mathrm{F}$ & 11 & 37 & A'simah & $\mathrm{F}$ & 12 & 35 \\
\hline 22 & Nadiyah & $\mathrm{F}$ & 11 & 23 & Adalah & $\mathrm{F}$ & 11 & 38 \\
\hline 23 & Sariyah & $\mathrm{F}$ & 13 & 25 & Abulwali & $\mathrm{M}$ & 8 & 14 \\
\hline 24 & Sarah & $\mathrm{F}$ & 13 & 18 & A'amal & $\mathrm{F}$ & 8 & 16 \\
\hline 25 & Huda & $\mathrm{F}$ & 18 & 19 & Salah & $\mathrm{M}$ & 12 & 11 \\
\hline 26 & Sulayman & $\mathrm{M}$ & 15 & 13 & Ammar & $\mathrm{M}$ & 13 & 12 \\
\hline 27 & Amjad & $\mathrm{M}$ & 14 & 29 & Luluah & $\mathrm{F}$ & 18 & 26 \\
\hline 28 & Abdullah & $\mathrm{M}$ & 11 & 40 & Bilal & $\mathrm{M}$ & 14 & 40 \\
\hline 29 & Abdulmajeed & $\mathrm{M}$ & 16 & 41 & Ziad & $\mathrm{M}$ & 12 & 39 \\
\hline 30 & Raghad & $\mathrm{F}$ & 15 & 31 & Ruqayah & $\mathrm{F}$ & 18 & 12 \\
\hline 31 & Hafsah & $\mathrm{F}$ & 14 & 22 & Asma'a & $\mathrm{F}$ & 15 & 11 \\
\hline
\end{tabular}




\begin{tabular}{|c|c|c|c|c|c|c|c|c|}
\hline 32 & Abdurrahman & $\mathrm{M}$ & 14 & 33 & Sumayah & $\mathrm{F}$ & 17 & 17 \\
\hline 33 & Akram & $\mathrm{M}$ & 14 & 36 & Kawthar & $\mathrm{F}$ & 13 & 25 \\
\hline 34 & Taqwa & $\mathrm{F}$ & 13 & 28 & Khawlah & $\mathrm{F}$ & 14 & 24 \\
\hline 35 & Salma & $\mathrm{F}$ & 12 & 15 & Tasneem & $\mathrm{F}$ & 18 & 39 \\
\hline 36 & Hadiyah & $\mathrm{F}$ & 18 & 29 & Amal & $\mathrm{F}$ & 10 & 33 \\
\hline 37 & Sayda & $\mathrm{F}$ & 18 & 28 & Sami & $\mathrm{M}$ & 10 & 45 \\
\hline 38 & Abdulkareem & $\mathrm{M}$ & 16 & 23 & Haneen & $\mathrm{F}$ & 10 & 16 \\
\hline 39 & Sadeq & $\mathrm{M}$ & 8 & 43 & Ayham & $\mathrm{M}$ & 16 & 23 \\
\hline 40 & Motaz & $\mathrm{M}$ & 10 & 9 & Sajidah & $\mathrm{F}$ & 18 & 23 \\
\hline Total & $40(20 \mathrm{M}+20 \mathrm{~F}$ & & 530 & 1022 & $40(20 \mathrm{M}+2$ & & 525 & 949 \\
\hline Mean & & -- & 13.25 & $25.55 \%$ & & -- & 13.12 & $23.72 \%$ \\
\hline
\end{tabular}

The reason behind the results' similarities was due to that the researchers aimed at creating two matched groups in order to ensure the validity and reliability of the research. Such procedure was appropriate as the outcomes of the two groups (Treatment/ experimental group and control group) yield similar results $(25.55 \%$ and $23.72 \%)$ to the pre-test for measuring the subjects' listening skill. In the experimental group as is seen in the Table 1, archived listening data from 40 individuals with different types of aphasias and language disorders were used to identify the accurate level students of special needs should be included in the pre-test. The results showed that only two subjects (Bayrout and Motaz) in the treatment group registered below 10 scores ( 8 and 9, respectively). The subject number 39 (Sadeq) scored the highest mark (43) and this may be accounted for because of the age (8).

In the control group, the reliability of the test was evaluated in light of the performance of all subjects in the group (40 individuals with various types of aphasia and language difficulties) who were selected to represent the full range of listening impairments. Results of the highest and lowest levels of the students were examined on the scale of lower than 10 scores and upper than all subjects. Looking at it statistically, Rashad and Sami's scores were found to be internally consistent in comparison to those of the treatment group ( 9 and 45, accordingly). Strictly, accuracy scores on these subjects were highly correlated with other scores of all subjects either those in the treatment group or those in the control group. In both groups, results' accuracy was extremely valid and reliable, and independent administrations of using the same methodology produced similar results to the two groups involved $(25.55 \%$ and 23 . $72 \%)$.

The two treatment groups of males and females performed 543 and 479 scores in the pre-test. Such scores are normal and have no significant meanings since we are talking here about pre-test. The same thing applies to the performance of the control group which scored 342 and 607 (males and females, accordingly). In fact, the significance of these results can be seen in light of the outcomes of the posttest. Consider:

Table 2. Performance of the subjects in the post-test: Comparison between the treatment and control groups

\begin{tabular}{|l|r|r|} 
No & Treatment/ Experimental group & Control group \\
\hline
\end{tabular}




\begin{tabular}{|c|c|c|c|c|c|c|c|c|}
\hline & Subject Name & 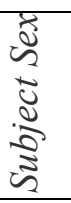 & 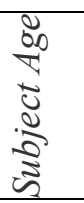 & 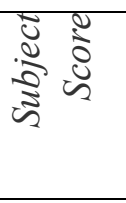 & Subject Name & 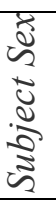 & 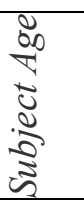 & 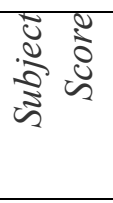 \\
\hline 1 & Saleh & $\mathrm{M}$ & 18 & 49 & Nada & $\mathrm{F}$ & 15 & 23 \\
\hline 2 & Majed & $\mathrm{M}$ & 12 & 58 & Hajar & $\mathrm{F}$ & 14 & 24 \\
\hline 3 & Saqr & M & 14 & 59 & Hamas & $\mathrm{F}$ & 8 & 39 \\
\hline 4 & Ali & $\mathrm{M}$ & 8 & 65 & Rashad & $\mathrm{M}$ & 12 & 12 \\
\hline 5 & Amatallateef & $\mathrm{F}$ & 12 & 89 & Omar & $\mathrm{M}$ & 9 & 14 \\
\hline 6 & Amatala'leem & $\mathrm{F}$ & 9 & 98 & Ashraf & $\mathrm{M}$ & 16 & 18 \\
\hline 7 & Badr & $M$ & 13 & 85 & Mohammad & $\mathrm{M}$ & 11 & 29 \\
\hline 8 & Tareq & M & 14 & 68 & Montaha & $\mathrm{F}$ & 14 & 35 \\
\hline 9 & Parees & $\mathrm{F}$ & 15 & 79 & Ayman & $\mathrm{M}$ & 13 & 34 \\
\hline 10 & Bayrout & $\mathrm{F}$ & 9 & 59 & Aayah & $\mathrm{F}$ & 10 & 19 \\
\hline 11 & Tammaah & $\mathrm{M}$ & 9 & 96 & Adham & $\mathrm{M}$ & 10 & 30 \\
\hline 12 & Taher & $\mathrm{M}$ & 17 & 57 & Nasser & $\mathrm{M}$ & 11 & 40 \\
\hline 13 & Baraah & $\mathrm{F}$ & 16 & 49 & Haylah & $\mathrm{F}$ & 17 & 23 \\
\hline 14 & Abrar & $\mathrm{F}$ & 11 & 94 & Tawfeeq & $\mathrm{M}$ & 13 & 43 \\
\hline 15 & Ahmad & $\mathrm{M}$ & 13 & 57 & Nour & $\mathrm{F}$ & 12 & 12 \\
\hline 16 & Fatimah & $\mathrm{F}$ & 16 & 87 & Najeebah & $\mathrm{F}$ & 18 & 11 \\
\hline 17 & Amatillah & $\mathrm{F}$ & 18 & 75 & Radha'a & $\mathrm{F}$ & 16 & 9 \\
\hline 18 & Abdullateef & $\mathrm{M}$ & 8 & 84 & Wafa'a & $\mathrm{F}$ & 15 & 17 \\
\hline 19 & Amriyah & $\mathrm{F}$ & 12 & 94 & Wajedah & $\mathrm{F}$ & 15 & 19 \\
\hline 20 & Abduljaleel & $\mathrm{M}$ & 12 & 57 & Sultan & $\mathrm{M}$ & 9 & 20 \\
\hline 21 & Kareemah & $\mathrm{F}$ & 11 & 59 & A'simah & $\mathrm{F}$ & 12 & 26 \\
\hline 22 & Nadiyah & $\mathrm{F}$ & 11 & 86 & Adalah & $\mathrm{F}$ & 11 & 28 \\
\hline 23 & Sariyah & $\mathrm{F}$ & 13 & 59 & Abulwali & $\mathrm{M}$ & 8 & 39 \\
\hline 24 & Sarah & $\mathrm{F}$ & 13 & 69 & A'amal & $\mathrm{F}$ & 8 & 22 \\
\hline 25 & Huda & $\mathrm{F}$ & 18 & 47 & Salah & $\mathrm{M}$ & 12 & 49 \\
\hline 26 & Sulayman & $\mathrm{M}$ & 15 & 58 & Ammar & $\mathrm{M}$ & 13 & 12 \\
\hline 27 & Amjad & $\mathrm{M}$ & 14 & 59 & Luluah & $\mathrm{F}$ & 18 & 34 \\
\hline 28 & Abdullah & $\mathrm{M}$ & 11 & 75 & Bilal & $\mathrm{M}$ & 14 & 12 \\
\hline 29 & Abdulmajeed & M & 16 & 98 & Ziad & M & 12 & 8 \\
\hline 30 & Raghad & $\mathrm{F}$ & 15 & 78 & Ruqayah & $\mathrm{F}$ & 18 & 14 \\
\hline 31 & Hafsah & $\mathrm{F}$ & 14 & 90 & Asma'a & $\mathrm{F}$ & 15 & 27 \\
\hline 32 & Abdurrahman & M & 14 & 59 & Sumayah & $\mathrm{F}$ & 17 & 36 \\
\hline 33 & Akram & $\mathrm{M}$ & 14 & 56 & Kawthar & $\mathrm{F}$ & 13 & 41 \\
\hline 34 & Taqwa & $\mathrm{F}$ & 13 & 40 & Khawlah & $\mathrm{F}$ & 14 & 28 \\
\hline 35 & Salma & $\mathrm{F}$ & 12 & 60 & Tasneem & $\mathrm{F}$ & 18 & 20 \\
\hline 36 & Hadiyah & $\mathrm{F}$ & 18 & 96 & Amal & $\mathrm{F}$ & 10 & 22 \\
\hline 37 & Sayda & $\mathrm{F}$ & 18 & 79 & Sami & $\mathrm{M}$ & 10 & 27 \\
\hline 38 & Abdulkareem & $\mathrm{M}$ & 16 & 89 & Haneen & $\mathrm{F}$ & 10 & 36 \\
\hline
\end{tabular}




\begin{tabular}{|r|r|r|r|r|r|r|r|r|}
\hline 39 & Sadeq & $\mathrm{M}$ & 8 & 88 & Ayham & $\mathrm{M}$ & 16 & 28 \\
\hline 40 & Motaz & $\mathrm{M}$ & 10 & 94 & Sajidah & $\mathrm{F}$ & 18 & 42 \\
\hline Total & $40(20 \mathrm{M}+20 \mathrm{~F})$ & & 530 & 2898 & $40(20 \mathrm{M}+20 \mathrm{~F})$ & 525 & 1022 \\
\hline Mean & & -- & 13.25 & $72.45 \%$ & & -- & 13.12 & $25.55 \%$ \\
\hline
\end{tabular}

As is mentioned in the objectives of this study, one of the aims was to investigate the effects of using audio-visual aids and CALI on the students of special needs and compare that with other groups were no educative means were used at all. The purpose of the posttest was to clarify the outcomes of the subjects' performance in general and that performance level of these subjects in the pre-test in particular. Again, researchers attempted to ensure the validity and reliability of the test by using such test to identify to what extent it can induce verbal working hearing improvement and decoding facilitation by stimulating the receptive organs in general and those related to the listening comprehension in particular through audio-visual aids and CALI. It can also help the SLTs and other experts in the field improve the appropriate educative aid that can elicit and stimulate the appropriate response and/ or interaction.

Compared with their scores in the pre-test, results of the subjects in the posttest, notably those in the treatment group were not expected. Unlike the scores of the control group's subjects which witnessed little improvement $(23.72 \%$ vs. $25.55 \%)$, the scores of those in the experimental group exhibited the characteristic of the milestone where there was remarkable change and significant difference $(25.55 \%$ vs. $72.45 \%)$. Undoubtedly, the reason was due to the use of audio-visual aids and CALI for they functioned as cause-effect solutions. Whereas the control group subjects scored similar marks like those of the two groups' pre-test $(8,9$, etc.), the marks of those in the treatment group were incomparable. This can be clearly seen in light of the least score registered in the group (40). Regardless the scores of the control group for both males and females in the posttest (415 vs. 607), the importance is only for treatment group's performance (males $=1411$, females $=1487$ ). The researcher believes that such high scores are due to the sex of the teacher (female) which makes her close to the females and make them, in turn, love her; therefore, understand all what she says. Such educative aids are recommended as treatment tools to overcome listening difficulties and problems relating to them.

\section{Conclusions \& Recommendations}

Aids to language teaching are of three broad categories: Conventional aids, technological aids (machines other than computer) and computer-assisted language learning (CALL). There are some techniques that can be effectively used for teaching language in general. These strategies can be used for teaching nearly all language aspects including the sound system, grammatical structures and vocabulary (language components) as well as teaching the four language skills and culture. Generally, educative aids are of three types. The first type includes visual aids: (e.g., realia, models, pictures/ drawings, posters, maps (geographic and city plans), boards, cards (flash cards, reading cards- Questions \& Answers), graphs, forms, menus, slides ( $35 \mathrm{~mm}$ and OHP), film strips, silent films, comic books and strips, facial diagrams, clock faces and hands, calendars, charts, letters of the alphabet and numbers, 
cross-word puzzles, etc.). The second type is related to audio aids (including lab) (e.g., audio cassette/ tape (reel) recorders, radio, phonograph records (record albums), CDs, conventional labs. The third type is that of audio-visual aids (e.g., video tapes, TV, DVD, sound films, synchronized audio recording with visual presentations (slides), action aids (e.g., dramatization, field trips, games, pantomime, etc. ) and multimedia (e.g., computer language teaching/ learning (CALT/ L)), the use of internet, interactive or not, etc.).

A very legitimate question here is: What is the importance of educative aids (Audio-visual aids and CALI) in speech language pathology? To answer such question, SLTs need to know the characteristics and benefits of audio-visual aids and CALI. Some of these features are relating to attracting attention, maintaining attention. Some SLTs emphasize that audio- visual aids and CALI can be used in matters relating to the clarification of concepts/ meanings of words and utterances. According to these SLTs, these educative aids participate in increasing the chances of remembrance by increasing means of association, saving time, simulation of language use, and presenting authentic language and natural settings for language use. Others add that audio-visual aids and CALI can be exploited to compensate for lack of experience of SLTs, individualize learning and instruction, involve of learners, give variety to the lesson, and provide instant feedback.

Computers in general and computer programs in particular were found to be successful in achieving transfer of trained language abilities in speed of processing to similar untrained tasks. They can be used as means of presentation of text and also as means of presentation of exercises and feedback (and/or evaluation). Moreover, one can implement them for other educational purposes where they can be effectively used as sources of texts and also as a means of providing a record of students' progress. In addition, computers are the best educative environments where one can easily find all types of electronic dictionaries (e.g., Thesauri, Sakhr, Atlas, Longman, Contemporary, Webster, etc.). Other available electronic references include grammatical/ usage information, information sources (encyclopedia, etc.), and internet access where communication takes place with others. Strictly, internet facilities found to be useful for teaching, references, consultation, interaction with others, practicing through chatting, learning individually or through collaboration (on assignments, etc.).

CALI requires some procedures to be undertaken before therapeutic sessions take place. Standing alone is the first procedure and this refers to two important points: Considering class complementary work, and language course (autonomous learning). Network is another procedure that SLTs should pay attention to. They should make sure that all necessary networks (e.g., local network), internet access, supplementary materials, language course (Autonomous learning), etc., are available. Nor must we forget to add also the feature of benefiting from computer mediated communications (CMC) (e.g., e-mail, chat, distant learning(, information tools ( different topics, language aids like dictionaries, and/ or using computer as a tool (word processing, spell checkers, grammar checker, word count).

Programmed instruction (self-teaching/ learning) can be used to break learning task/ information into small bits, present these in frames which require response by the learner and then provide feedback by the system. In fact, a connection ought to be made between the uses 
of programmed instruction and CALI since the former is a part of the latter. Such uses of the programmed instruction require us to mention something about the advantages of CALI. These include: Individualization, instant feedback, combining efforts of different experts, assessment, follow-up learner's progress, providing diagnostic report on learners, provision of authentic materials, use of multimedia, combination of different resources (lexical, grammatical, cultural...) and use of corpus linguistic facilities (such as concordancers- key word in context (KWIC)).

Psychoneurolinguistically speaking, human language can be analyzed into sounds (phonemes), words and/ or sentences. These sounds and sentences can be classified into segmental and supra-segmental phonemes and paragraphs. Instant testing/ evaluation of learners' performances are needed here as this gives us instant feedback. Two basic types should not be neglected here that are the linear programming (move on a single track $(1,2$, $3 . .$.$) , and branched/ branching programming: move in different directions, based on$ performance (e.g., Answer A leads to frame 4, Answer B leads to frame 10, Answer C leads to frame 1 , and so forth)

Audio-visual aids and CALI can be used for listening comprehension, but before that some requirements for teaching listening comprehension have to be taken into consideration. These include:

- Sound discrimination.

- Understanding lexical items in context.

- Understanding grammatical structures \& their functions.

- Recognizing discourse signals/ markers (e.g., transition expressions).

- Understanding paralinguistic signals (e.g., gestures.).

Some other considerations that should be taken into account are related to the nature of text itself. Linguistically, there are five (5) types of texts:

(1) Authentic (e.g, airport announcement, newscast, etc.).

(2) Simulated (an imitation of the authentic text).

(3) Live (face to face meeting, interview, etc.).

(4) Recordings from media (to be given later to the students in the class).

(5) Fabricated/ artificial (made by the teacher).

Nor must we forget the mode of presentation which can be live, audio-video, audio recording or reading only.

For listening comprehension, some of the audio-visual aids and CALI that SLTs can implement when teaching students of special needs are graphic aids (along with oral text) (e.g., simple pictures, picture sets/ sequences, composite picture, graphs, maps...etc. Questions vary based on the objectives of the message that SLT aims to encode. For 
example, matching picture and oral text/ identifying picture (based on oral text), Yes/ No questions, true/ false/ do not know (T/F/DK) questions (based on pictures or oral texts) are some of these preferable questions. He/ she can also ask students to follow instructions (actions) (e.g., drawing, tracing directions on map, etc.). Yet, there are some requirements for listening comprehension that SLTs should consider before undertaking the speech language lesson. These include: Sound discrimination, understanding lexical items in context, understanding grammatical structures and their functions, recognizing discourse signals/ markers (e.g., transition expressions), and understanding paralinguistic signals (gestures). Regarding the visual aids that can be used along with oral text, one can easily identify five (5) types of activities or questions to be given here:

1- Pictures: Simple pictures, picture sets/ sequences, composite pictures, etc.

2- Matching picture and oral text/ identifying picture.

3- Yes/ No questions (based on the picture's content and / or given text).

4- True/False/Don't' Know (based on pictures and/or texts).

5- Following instructions (actions):

a. Physical response.

b. Drawing, coloring.

c. Tracing directions on a street map.

d. Party games (rumour).

Looked at it from a psychoneurolinguistic viewpoint, when SLPTs want to teach listening comprehension, they must do that for a purpose. Purposes for recording materials should include: Practicing/ testing listening comprehension, practicing/ testing pronunciation (segmental and supra-segmental features), practicing grammatical structures (e.g., pattern drills), practicing reading, memorizing dialogues and using them and teaching / testing dictation. However, there are some general rules and procedures for performing that perfectly. These rules and instructions can be listed as follows:

$\checkmark$ Source of the recording should be good (accurate on the phonemic level at least), clearly audible and intelligible, adequate for target learners. (Preferably authentic or by native speaker).

$\checkmark \quad$ Instructions (i.e., rubrics) should be very clear, preferably coupled with examples.

$\checkmark \quad$ Rate of delivery should be adequate (normal).

$\checkmark$ Silence blanks for repetition or practice should be suitable. (Usually twice the time used by the master recording or professional person).

$\checkmark$ Provision of reinforcement when necessary.

$\checkmark \quad$ Making adequate pauses, if needed.

$\checkmark$ Making breaks/ pauses at proper points.

$\checkmark \quad$ In teaching dialogues, we break the utterance into segments, starting from the end of the sentence (to maintain proper intonation).

$\checkmark \quad$ Segmented utterances and /or text should be delivered as wholes as well at normal rate.

$\checkmark$ Giving full information on content. (Book, lesson, part of lesson, etc.).

$\checkmark \quad$ Leave adequate blank at the beginning and end of the tape. 
Listening comprehension assessments are commonplace in the field of teaching receptive skills (reading and listening). Pre-and-posttest is used to document variations and differences in the capability of listening comprehension in target groups. Statistically, true change scores may be affected in different ways. For example, they may be distorted by measurement error, repeated exposure to the assessment instrument, or person variables. The present study provides reliable and valid information, derived from a sample of 80 aphasic subjects aged 8 years and older (up-to18). All subjects were given pre-and-posttests within 4 months (before and after a semester). Figure 1 concludes the outcomes of the pre-and-posttests. Consider:

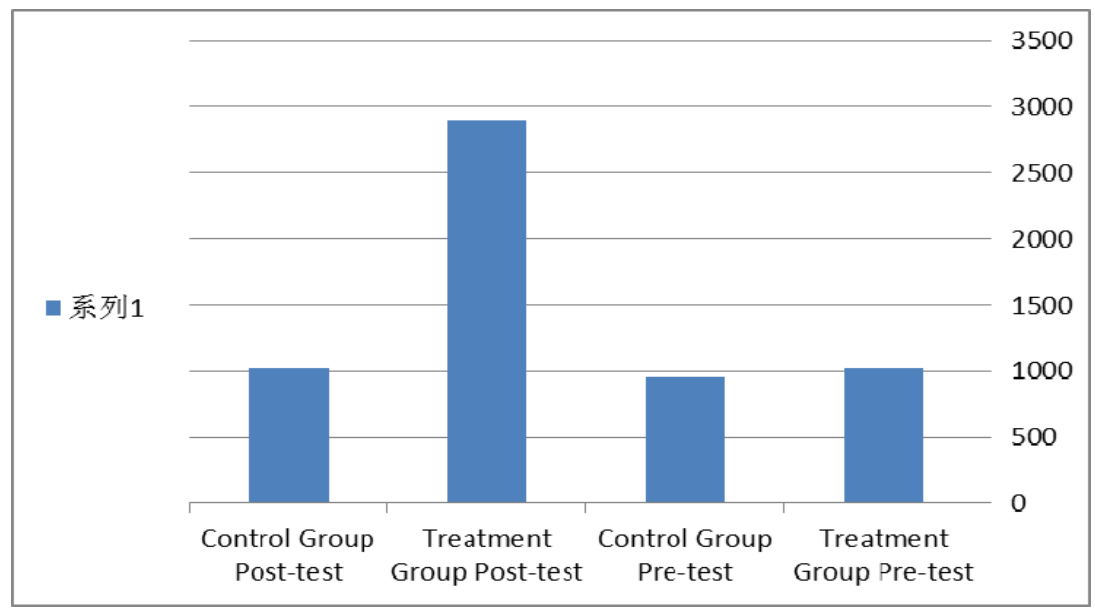

Figure 1. Outcomes of treatment and control groups' pre-and-posttests: Comparison

As is seen in the above mentioned figure, results showed that the performance level of the treatment group has been increased in comparison to the control group and the performance of the same group in the pre-test. Such difference is certainly a direct result of the intervention of audio-visual aids and CALI. The results of this study agree with those of many other researchers (Ahmed, 2012; Gower \& McDowall, 2012; Wright \& Uchanski, 2012: Pike, 2012: Marino, et al., 2013; Ching-Kun, et al., 2013).

Compared with males, females' performance is higher (1411 vs. 1487). Figure 2 summarizes these scores. Compare:

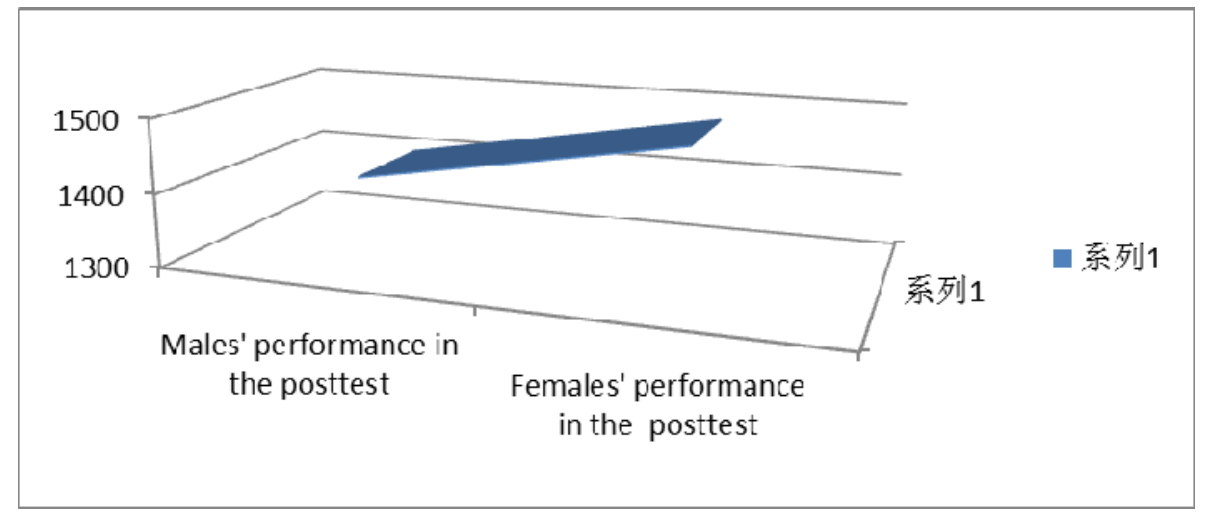

Figure 2. Males and females performance in posttest: Comparison 
These findings may help SLTs and researchers to characterize with greater precision the temporal and permanent changes in listening comprehension in students of special needs. They further cast light on the importance of using educative aids for teaching receptive skills in general and listening comprehension in particular.

\section{Acknowledgement}

First and foremost, my utmost gratitude to Prof. Kebbe whose sincerity and encouragement I will never forget. Prof. Kebbe has been my inspiration as I hurdle all the obstacles in the completion this research work.

\section{References}

Ahmed, S. S. (2012). Media pedagogy - the medium is the message. Paper presented at the (64), 425-430. Retrieved from http://search.proquest.com/docview/1220675367?accountid=44936.

Álvarez, G. (2012). New technologies in the university context: The use of blogs for developing students' reading and writing skills. RUSC, 9(2), 185-198. Retrieved from http://search.proquest.com/docview/1030155853?accountid=44936.

Anson, C. M., \& Schwegler, R. A. (2012). Tracking the mind's eye: A new technology for researching twenty-first-century writing and reading processes. College Composition and Communication, 64(1), 151-171. Retrieved from http://search.proquest.com/docview/1081830986?accountid=44936.

Block, K., Amie, A., Chery, J., Gina, N., Peggy, A., Deborah, W., \& Sara, H. (1993). "Definitions of Communication Disorders and Variations", Ad Hoc Committee on Service Delivery in the Schools. ASHA, 13-14. http://dx.doi.org/10.1044/policy. RP1993-00208, retrieved 2010-08-07.

Bradham, S. T. (2012). From the ear to the brain: Advances in understanding auditory function, technology and spoken language development. The Volta Review, 112(2), 149-180. Retrieved from http://search.proquest.com/docview/1095617934?accountid=44936.

Brown, A., Stevens, R., \& Pettifer, S. (2013). Making Graph-Based Diagrams Work in Sound: The Role of Annotation. Human-Computer Interaction, 28(3), 193-221. http://dx.doi.org/10.1080/07370024.2012.697010.

Chen, I., \& Yen, J. (2013). Hypertext annotation: Effects of presentation formats and learner proficiency on reading comprehension and vocabulary learning in foreign languages. Computers \& Education, 63, 416-423. http://dx.doi.org/10.1016/j.compedu.2013.01.005.

Damoiseaux, J., Mallet, K., Vaessen, M., Austen, J., \& Jan-Willem, C. T. (2012). Automatic reading of ANCA-slides: Evaluation of the AKLIDES system. Clinical \& Developmental Immunology, 762874. http://dx.doi.org/10.1155/2012/762874.

Davies, G., \& Higgins, A. (1992). Language and Language Learning. London: CILT.

Devimeenakshi, K., \& Maheswari, C. N. (2012). Using original methods in teaching english 
language to foreign students (chinese) in indian classroom. English Language Teaching, 5(9), 166-177. Retrieved from http://search.proquest.com/docview/1039540643? accountid=44936. http://dx.doi.org/10.5539/elt.v5n9p166.

Diaz-Maurin, F., \& Giampietro, M. (2013). A "Grammar" for assessing the performance of power-supply systems: Comparing nuclear energy to fossil energy. Energy, 49, 162-177.

Fuenzalida, V., \& Sjöberg, U. (2012). The cultural opportunity of children's television public policies in digital Television/A response to "the cultural opportunity of children's TV: Public policies in digital television". Communication Research Trends, 31(3), 4-22. Retrieved from $\mathrm{http}: / /$ search.proquest.com/docview/1112924145?accountid=44936.

Gessesse, C., \& Sileshi, L. (2013). The Semiotics of HIV/AIDS Bill-Boards and Their Communication Implications: The Case of Bahir Dar and Gondar Towns in Ethiopia. Online Journal Of Communication \& Media Technologies, 3(1), 240-275.

Gilakjani, A. P. (2012). A study on the impact of using multimedia to improve the quality of english language teaching. Journal of Language Teaching and Research, 3(6), 1208-1215. Retrieved from http://search.proquest.com/docview/1272283949?accountid=44936. http://dx.doi.org/10.4304/jltr.3.6.1208-1215.

Gower, L., \& McDowall, J. (2012). Interactive music video games and children's musical development. British Journal of Music Education, 29(1), 91-105. doi: http://dx.doi.org/10.1017/S0265051711000398.

Harcourt, B., \& Templer, B. (2005). "Towards a People's English: Back to BASIC in EIL". Humanising Language Teaching, 1-5.

Henderson, J. M., \& Luke, S. G. (2012). Oculomotor inhibition of return in normal and mindless reading. Psychonomic Bulletin \& Review, 19(6), 1101-1107. Retrieved from http://search.proquest.com/docview/1268714917?accountid=44936.

http://dx.doi.org/10.3758/s13423-012-0274-2.

Iram, S. (2012). Reading needs, facilities and problems of visually impaired people. Pakistan Journal of Library and Information Science, (13), 1-H1. Retrieved from http://search.proquest.com/docview/1242449874?accountid=44936. Available at http://pu.edu.pk/home/journal/8. ISSN 1680-4465.

Ismail, A. S., Hamed, M. A., \& Abdurrahman, G. A. (2012). Employing reading and writing computer-based instruction in english as a second language in elementary schools. International Journal of Business and Social Science,3(12), 3-4. Retrieved from http://search.proquest.com/docview/1022655978?accountid=44936.

Khaliq, M. F., Noorani, M. M., Siddiqui, U. A., \& Anwar, M. (2012). Physicians reading and writing practices: A cross-sectional study from civil hospital, karachi, pakistan. BMC Medical Informatics and Decision Making, 12(1), 76. http://dx.doi.org/10.1186/1472-6947-12-76. http://www.biomedcentral.com/1472-6947/12/76.

Kirk, K. I., Prusick, L., French, B., Gotch, C., Eisenberg, L. S., \& Young, N. (2012). 
Assessing spoken word recognition in children who are deaf or hard of hearing: A translational approach. Journal of the American Academy of Audiology, 23(6), 464-75. Retrieved from http://search.proquest.com/docview/1022698261?accountid=44936. DOI: 10.3766/jaaa.23.6.8.

Klingenberg, O. G. (2012). Conceptual understanding of shape and space by braille-reading norwegian students in elementary school. Journal of Visual Impairment \& Blindness, 106(8), 453-465. Retrieved from http://search.proquest.com/docview/1034974451 ?accountid=44936.

Levesque, R. (2007). SPSS Programming and Data Management: A Guide for SPSS and SAS Users, Fourth Edition. SPSS Inc., Chicago Ill. PDF, 1-3. ISBN 1-56827-390-8.

Levy, M. (1997). CALL: context and conceptualisation. Oxford: Oxford University Press.

Macleod, A., Fabiano-Smith, L., Boegner-Pagé, S., \& Sami Fontolliet, S. (2013). Simultaneous bilingual language acquisition: The role of parental input on receptive vocabulary development. Child Language Teaching \& Therapy, 29(1), 131-142. http://dx.doi.org/10.1177/0265659012466862.

Manoli, P., \& Papadopoulou, M. (2012). Graphic organizers as a reading strategy: Research findings and issues. Creative Education, 3(3), 348-356. Retrieved from http://search.proquest.com/docview/1022986447? accountid=44936.

http://dx.doi.org/10.4236/ce.2012.33055.

Marino, R., Linton, N., Eikelboom, R. H., Statham, E., \& Rajan, G. P. (2013). A comparative study of hearing aids and round window application of the vibrant sound bridge (VSB) for patients with mixed or conductive hearing loss. International Journal Of Audiology, 52(4), 209-218. doi:10.3109/14992027.2012.750431.

Mead, A. R., Bradwell, R. P., \& Stokes, G. P. (1999). Advanced atlas of autoantibody patterns. Birmingham: The Binding Site. ISBN 0704485109.

Onnis, L., \& Thiessen, E. (2013). Language experience changes subsequent learning. Cognition, 126(2), 268-284. http://dx.doi.org/10.1016/j.cognition.2012.10.008.

Pavan, A., \& Baggio, G. (2013). Linguistic Representations of Motion Do Not Depend on the Visual Motion System. Psychological Science (Sage Publications Inc.), 24(2), 181-188. http://dx.doi.org/10.1177/0956797612450882.

Peek, H. B. (2010). "The Emergence of the Compact Disc". IEEE Communications Magazine 48 (1), 10-17. http://dx.doi.org/10.1109/MCOM.2010.5394021.ISSN 0163-6804.

Peinhardt, R. D., \& Hagler, D. (2012). Peer coaching to support writing development. Journal of Nursing Education, 52(1), 24-8. doi: http://dx.doi.org/10.3928/01484834-20121121-02.

Perea, M. (2012). Revisiting huey: On the importance of the upper part of words during reading. Psychonomic Bulletin \& Review, 19(6), 1148-1153. Retrieved from http://search.proquest.com/docview/1268714918?accountid=44936. 
http://dx.doi.org/10.3758/s13423-012-0304-0.

Pike, P. D. (2012). Sight-Reading Strategiews: For the beginning and intermediate piano student A fresh look at A familiar topic. The American Music Teacher, 61(4), 23-28,3. Retrieved from http://search.proquest.com/docview/922376823?accountid=44936.

Sigrist, R., Rauter, G., Riener, R., \& Wolf, P. (2013). Augmented visual, auditory, haptic, and multimodal feedback in motor learning: A review. Psychonomic Bulletin \& Review, 20(1), 21-53. Retrieved from http://search.proquest.com/docview/1314366722? accountid= 44936 . http://dx.doi.org/10.3758/s13423-012-0333-8.

Su, S., \& Liu, C. (2012). Teaching listening comprehension skills: A test-orientated approach. Journal of Language Teaching and Research, 3(3), 458-465. Retrieved from http://search.proquest.com/docview/1019434925?accountid=44936.

http://dx.doi.org/10.4304/jltr.3.3.458-465.

Swimelar, S. (2013). Visualizing International Relations: Assessing Student Learning Through Film. International Studies Perspectives, 14(1), 14-38. http://dx.doi.org/10.1111/j.1528-3585.2012.00467.x.

Thrasher, A. (1996). "DVD: coming soon to your PC?". Computer Shopper 16 (3), 189.

Wolf, M., Ullman-Shade, C., \& Gottwald, S. (2012). The emerging, evolving reading brain in a digital culture: Implications for new readers, children with reading difficulties, and children without schools. Journal of Cognitive Education and Psychology, 11(3), 230-240. Retrieved from http://search.proquest.com/docview/1124437587?accountid=44936.

Wright, R., \& Uchanski, R. M. (2012). Music perception and appraisal:: Cochlear implant users and simulated cochlear implant listening. Journal of the American Academy of Audiology, 23(5), 350-65; quiz 379. Retrieved from http://search.proquest.com/docview/1015339105?accountid=44936.

http://dx.doi.org/10.3766/jaaa.23.5.6.

\section{Glossary}

ANCA (Anti-neutrophil cytoplasmic antibodies) = These are a group of autoantibodies and monocytes that are detected as a blood test in a number of autoimmune disorders, but are particularly associated with systemic vasculitis. ANCA often "show combinations of both cytoplasmic and perinuclear staining." (Mead, et al., 1999: p.1)

CALL/I/T (Computer-assisted/aided language learning/instruction/teaching) $=$ It is defined as "the search for and study of applications of the computer in language, teaching and learning." (Levy, 1997: p.1). While CALL is related to students, CALT and CALI "fell out of favor among teachers". In that sense, it can be said that while in the former term, the student-centered approach is the dominant perspective, in the latter; a teacher-centered approach is more preferred. CALI/T exhibits all characteristics of English language teaching (ELT) (Davies G. \& Higgins, 1992: p.3).

CD $($ Compact Disc $)=$ It is used for storage of data. It was in March 1974, during a meeting 
of the audio group, two engineers from the Philips research laboratory recommended the use of a digital format on the $20 \mathrm{~cm}$ optical disc, because an error-correcting code could be added." (Peek, 2010: p. 10).

CMC (Computer-mediated communication) $=$ According to McQuail (2005), CMC is seen as "any communication that occurs through the use of two or more electronic devices." (McQuail, 2005: p.1)

DVD (Digital versatile disc) $=$ It is a digital optical disc storage format. The DVD specification provided a storage capacity of $4.7 \mathrm{~GB}$ for a single-layered, single-sided disc and 8.5 GB for a "dual-layered, single-sided disc." (Thrasher, 1996: p. 16).

ESL/ EFL (English as a second/ foreign language) = It can be defined as the use or study of English by speakers with different native languages in English speaking countries. Unlike ESL, EFl refers to the teaching of English in a non-English-speaking region. Such differences occurred "during the development of English in the 1930s." (Harcourt \& Templer, 2005: p.2).

KWIC (Key word in Context) $=$ It is considered the most common format for concordance lines "especially in the phrase" (Collins English Dictionary, 2003).

OHP (overhead projector) = It is a variant of slide projector that is used to display images to an audience. In the definition of dictionary, "overhead projector is capable of projecting enlarged images of written or pictorial material onto a screen or wall from a transparency placed horizontally below the projector and lighted from underneath"(The American heritage dictionary of the English language, 2009).

SLTs (Speech-Language Therapists) = They are specialized in communication disorders as well as swallowing disorders. They are also called Speech Pathologists (Block et al., 1993, P. 23)

SPSS (Statistical program/package/product/ for social sciences/ and service solution) $=$ It is a software package used for statistical analysis and is among the most widely used programs for statistical analysis in social science. Levesque (2007) listed some statistical operations that are normally undertaken by SPSS software. These include: "Descriptive statistics (Cross tabulation, descriptive frequencies, exploration, etc.), descriptive ratio statistics, bivariate statistics (means, t-test, ANOVA, correlation (e.g., bivariate, and partial distances), and nonparametric tests.), and prediction for numerical outcomes (linear regression and prediction for identifying groups (actor analysis, and cluster analysis.)"(Levesque, 2007: p. 392)

\section{Copyright Disclaimer}

Copyright reserved by the author(s).

This article is an open-access article distributed under the terms and conditions of the Creative Commons Attribution license (http://creativecommons.org/licenses/by/3.0/). 